\title{
Marketing Indicators and Effective Patronage of the University of Uyo Library
}

\author{
Dr. Ima-M. P. Usoro \\ University of Uyo, Main Library, University of Uyo, Nigeria.
}

\begin{abstract}
The study investigated marketing indicator and effective patronage of University of Uyo Library in the University of Uyo library. To carry out the study, two objectives, research questions, and hypotheses were formulated. The survey research design was adopted for the study. The population and sample of the study was 62 library staff in the University of Uyo Library using census sampling technique. A researcher developed questionnaire titled Marketing Indicators and Effective Patronage Questionnaire (MIEPQ) was developed to obtain data for the study. Mean and standard deviation was used to answer research questions while independent $t$-Test was used to test the hypotheses at .05 level of significant. The findings from the study showed that marketing indicator such as resources promotion, public relations and library publicity have significant influence on effective patronage of University of Uyo library resources. The study recommended among other things that the library management should utilize social media in marketing their University of Uyo Library and service to increase user patronage.
\end{abstract}

Key words: Marketing Indicator, Resource Promotion, Public Relation, Effective Patronage

DOI: $10.7176 / \mathrm{IKM} / 10-7-07$

Publication date: November $30^{\text {th }} 2020$

\section{INTRODUCTION}

Information is an important resource and an indispensable factor for promoting the development of a society in the twenty first century. Rowley (2001) observed that information has been called, the fifth need of man, ranking after air, water, food and shelter. Similarly, Luck (2002) opined that information is the life blood of planning, directing, and controlling any enterprise. This is because it makes the satisfaction of the demands of the population possible in an efficient way. The library therefore stands as an important institution in the provision of University of Uyo Library that support the intellectual and overall development of the members of its parent institution.

In recent years, the library does not just exist for the acquisition of University of Uyo Library for the needs of the parent community but it also ensures that the resources so acquired are known to the community of users. According to Afebende and Ebaye (2008), the effectiveness of a library does not depend on only its collection or resources and other facilities per se, but also on the success of its exploitation and use. Nwokedi and Ogundare (2005) asserted that one of the major objectives of any library is to ensure that maximum use is made of its resources and services.

This assertion brings to fore the importance of marketing in the library. For today's libraries, marketing is creating a set of activities that will include understanding user's needs, identifying resources and services, building users relationships and creating 'marketing mix' (Welch, 2006). Unlike the traditional marketing approach that is organization-focused and for a specific product, libraries and information agencies are user-focused. They focused on the users and how to strategies in order to promote University of Uyo Library to satisfy the users. In order to thrive, University libraries need to attract users, generate and raise awareness on the available services and resources. This study therefore seeks to find out how marketing indicators influence effective patronage of University of Uyo library.

\subsection{Statement of the Problem}

University libraries all over the world occupy an indispensable position in the provision of quality university education. They are established and mandated to provide University of Uyo Library and services that support the teaching, learning and research of their parent institutions. It is on record that university libraries strive to provide the needed University of Uyo Library and services to satisfy the ever increasing level of students' need.

However, observations by the researcher have shown that these resources and services are not effectively 
utilized by students leading to low patronage of University of Uyo Library in University of Uyo library. This problem is being attributed to a number of factors such as ignorance of the users and poor information service delivery. These problems have therefore raised varied opinions in the minds of the people. Some people believe that ignorance of the users depends on lack of publicity and accurate public relations between the user and the staff while some assume that poor information delivery is as a result of lack of promotion of the resources for open accessibility. The question now is, could low patronage of University of Uyo Library in the library be as a result of inadequate publicity and inaccurate public relation? Or could it be as a result of lack of promotion of the resources by the library?

In view of the above statement, this study therefore seeks to investigate library marketing indicators and effective patronage of University of Uyo Library.

\subsection{Objectives of the study}

The main objective of the study is to examine marketing indicators and effective patronage of the University of Uyo library. Specifically, the study sought to:

1) Determine the influence of resource promotion on effective patronage of University of Uyo library.

2) Determine the influence of library public relations on effective patronage of University of Uyo library.

\section{$1.3 \quad$ Research Questions}

The study answered the following research questions:

1) What is the influence of resource promotion on effective patronage of University of Uyo library?

2) What is the influence of library public relations on effective patronage of University of Uyo library?

\subsection{Hypotheses}

The following null hypotheses guided the study and was tested at 0.05 level of significance:

1. There is no significant influence of resource promotion on effective patronage of University of Uyo library.

2. There is no significant influence of library publicity on effective patronage of University of Uyo library.

\subsection{LITERATURE REVIEW}

\subsubsection{Resource Promotion and effective Patronage of University Libraries}

Resource promotion ensures university library's profitability through increased patronage. According to Loudon and Bitta (2002), resource promotion plays a significant role in the decisions which help the library to achieve its organizational objectives. Therefore, librarians need to develop marketing programmes that will not only reinforce clienteles' commitment but also encourage continuous utilization of the library resources. A part of the functions of resource promotion is not only to reinforce commitment of clienteles but to encourage repeated patronage for the library.

Resource promotion in library and information science has a newer meaning. It finds deep roots in social media. It is a set of techniques which is aimed at reinforcing the basic values of the library in a changing environment and at the same time meeting the needs of the library clientele. Essentially, resource promotion is the means through which users are informed on what the library does and what the library can do. Promoting library service has several benefits which include but not limited to: increased usage, increased value in the organization, education of users and changing of users' perceptions. Ezeani (2011) asserts that librarians desiring to connect constantly with their clients with an eye to increasing users' satisfaction through resource promotion must make a social presence using social media like Facebook or MySpace. Moreover, Microblogging sites like Twitter, blog, may also be used.

Facebook is a platform that features interactions between users. Facebook users can create a friend list right after membership process and can specify those who can or cannot take part in the interaction (friend selection and limitation of authority) when they sign in. One of the primary uses of Facebook by academic libraries is to promote the library with a library homepage. Libraries advertise hours, locations, website information, newly acquired materials. According to Fakas (2007), library Facebook can be linked to the library's website and as such Facebook page acts as a portal to the library. Since students frequently use outside search engines for academic research, even a basic Facebook page can serve as a reminder to users on the resources available in an academic 
library. Wan (2011) added that university libraries can use facebook to provide updates on library services such as new reference services, document delivery or research supports. Some libraries may also put up post related to library collections such as updates or promotions of electronic and print collections, database trials and other research resources. Libraries also create event invitations for programs as an additional forum to promote library activities (Chu and Meulemans, 2008).

A blog can be used for promoting library and University of Uyo Library and services. It can be used in a library for outreach, dissemination of information, building library image, internal and external communication, highlighting new and valuable recently added materials. Ekoja (2011) opines that blogs are very helpful in promoting library services like new acquisitions, opening hours, library events and programmes or online discussions. They can also be used for supporting the activities of the parent communities of libraries such as community news about festivities, ceremonies or sports. Dickson and Holley (2010) added that librarians can post news about the library as well as events occurring in the library using blog. Librarians can periodically post messages, share information on a particular subject or issues both in the institutions and government and allow users to comment or contribute to the content with the help of blog.

Twitter as a tool for resource promotion relies on messaging service, whether it uses a cell phone, instant messenger, like Yahoo Messenger or through specific websites. It allows the user to send messages to friends and family quickly and easily. Twitter only asks one question, "What are you doing?" As long as an answer is 140 characters or less, it is possible for thousands of people to see the answer immediately (Marion and Omotayo, 2010). Waddell and Barnes (2012) note that the ease of posting and sharing information on Twitter makes it an essential tool for libraries to reach their users. Librarians in Nigeria can use this platform to give users firsthand information on the on-going national election. Users can send instant messages (IM) on complaints or ask questions on a particular issue and get a feedback on the spot using twitter. University libraries use Twitter accounts to notify users of new relevant items from collection and events. Other types of social media librarians use in promoting library and University of Uyo Library are YouTube, wikis or Flickr.

Thus, resource promotion becomes an integral part of the marketing strategy for reaching the target users and it is the responsibility of librarians to combine elements of promotional strategies, which is promotional mix into coordinated plans. According to Kotler, Armstrong and Harry (2007), resource promotion is projected to increase the patronage of the library as well as create a stronger and quicker response from clients.

\subsubsection{Library Public Relations and effective Patronage of University Libraries}

Public relations connote a well-arranged programme of action for daily operations to the direction in which a library is moving and will move, including the aim and quality of services and the manner in which it co-operates with opinion forming groups. According to Namara (2010), public relations is defined as ongoing activities to ensure the overall organization has a strong image. Also, Laulenglager (2003) opined that public relation is the management function which evaluates public attitudes, identifies the policies and procedures, of an individual or an organization with the public interest and plans and executes a program of action to earn public understanding and acceptance.

Murray (2005) viewed public relation as the practice of creating, promoting, or maintaining good and a favorable image among the public toward an institution. In relation to academic libraries, Capriotti and Moreno (2006) asserted that academic libraries like other organisations can benefit from public relations in terms of their relationships with clienteles, employees, investors, suppliers, or other interested members of the community. According to O'Connor (2001), some of the main goals of public relations in a library are to create, maintain, and protect the library's reputation, enhance its prestige, and present a favorable image. Studies have shown that clienteles often base their patronage decisions on a library's frequent utilization, so public relations can have a definite impact on resource utilization. Public relations can be an effective part of a library's overall marketing strategy.

Another major public relations goal is to create goodwill for the organization. According to Long, (2008) and Kunaka (1998) the aims of public relations to libraries are:

1. To create an awareness among policy makers of the importance of information and the need to establish/upgrade library services to ensure easy access to information

2. To create better understanding of the role of the librarian, to improve the image of librarian in the society.

3. To create public appreciation of the role of the library in people's daily lives. 
4. Establishing favorable press relations to get news about the library on a regular basis

5. Creating publicity for specific services and resources and to create and maintain awareness of library capabilities in the community

6. Maintaining awareness of laws and regulations that affect libraries and lobbying to ensure legislation that helps libraries provide effective services.

7. Watching for community and national trends and issues that impact the library's image and informing the library's administrators

The mission statement of any library should be to satisfy the information needs of users at the right time and place. The only way to accomplish this mission, libraries should effectively market library's resources and services. Whatever option is chosen, a librarian is ultimately responsible for its public relations. While communication is the essence of public relations, an effective public relations campaign is based on action as well as words. Whether it is practiced formally or informally, public relations is an essential function for the survival of any organization. Libraries cannot afford to neglect public relations. It is possible to vastly improve a library's image within its community while also controlling public relations expenditures. Starck and Kruckeberg (2003) asserted that many libraries recognize the value of public relations as a strategic marketing tool they can use to increase patronage of their resources and services. Whether used alone or as part of an integrated marketing campaign, public relations can contribute to resources promotion in many ways. Namara (2010) opined that public relations are conducted through various media e.g. newspapers, television, radio, etc.

\subsection{METHODOLOGY}

This study adopted the descriptive survey design. According to Osuala (2002), the descriptive survey design is the design suitable for collection of data based on the opinion of people. This design is considered appropriate for the study because it will enable the collection of data from the respondents on the marketing indicators and effective patronage of University of Uyo library. The population and sample of this study comprised 62 library staff (23 professional and 39 senior para professional librarians) of the University of Uyo library using the census sampling technique. The census was considered appropriate because the population of the study is small and the size is manageable. A Questionnaire titled "Marketing Indicators and Effective Patronage Questionnaire (MIEPQ)" was the instrument used for collecting data for the study. The questionnaire was divided into 3 sections. Section A contained demographic information of the respondents, Section B contained items on the independent variable, while section $\mathrm{C}$ contained information on dependent variables and the items were formulated in line with the research questions and hypotheses. The instrument used a four point rating scale of Strongly Agreed $(S A=4)$, Agreed $(A=3)$, Disagreed $(D=2)$ and Strongly Disagreed $(\mathrm{SD}=1)$. Two experts (one each from LIS and Measurement and Evaluation) scrutinized and validated the research instrument to confirm its clarity, appropriateness of language, ability to elicit accurate information and suitability in line with the objectives of the study. 62 copies of the questionnaire was distributed and returned with valid response for data analysis. The data collected was analysed using Mean and Standard Deviation for the research questions and independent t-Test for the hypotheses at 0.05 level of significance.

\subsection{RESULTS AND DISCUSSIONS}

Research Questions One: What is the influence of resource promotion on effective patronage of University of Uyo Library? 
Table 1: Summary of Responses on influence of Resource Promotion on Effective Patronage of University of Uyo Library

\begin{tabular}{|l|l|l|l|l|l|l|l|l|}
\hline S/N & \multicolumn{1}{|c|}{ ITEMS } & SA & A & D & SD & MEAN & S.D & DECISIONS \\
\hline 1 & $\begin{array}{l}\text { Current information resources are } \\
\text { always acquired for the library }\end{array}$ & 18 & 23 & 13 & 8 & 2.93 & .24 & Significant \\
\hline 2 & $\begin{array}{l}\text { Displaying pattern of the new arrivals } \\
\text { in the library is very effective }\end{array}$ & 21 & 16 & 14 & 11 & 3.14 & .25 & Significant \\
\hline 3 & $\begin{array}{l}\text { The library sponsors educative program } \\
\text { to encourage the users. }\end{array}$ & 11 & 13 & 24 & 14 & 2.13 & .18 & Insignificant \\
\hline 4 & $\begin{array}{l}\text { We do exhibitions of books for users } \\
\text { regularly. }\end{array}$ & 22 & 20 & 12 & 8 & 2.88 & .22 & Significant \\
\hline 5 & $\begin{array}{l}\text { We actively use our social media } \\
\text { platform to disseminate information to } \\
\text { our clients. }\end{array}$ & 9 & 12 & 18 & 23 & 2.03 & .17 & Insignificant \\
\hline
\end{tabular}

Significant Mean Value $=2.6$

Table 1 above presents the item by item mean responses of the Influence of resources promotion on effective patronage of University of Uyo Library. The significant mean score is 2.6. Items 1, 2 and 4 are significant because their mean scores is greater than the significant mean value of 2.6 while items 3 and 5 are insignificant because their mean scores are less than the significant mean value of 2.6. The overall decision is that resource promotion has a significant influence on the effective patronage of University of Uyo Library.

Research Question 2: What is the influence of library public relations on effective patronage of University of Uyo Library?

Table 2: Summary of Responses on Influence of Library Public Relations on Effective Patronage of University of Uyo Library

\begin{tabular}{|l|l|l|l|l|l|l|l|l|}
\hline S/N & \multicolumn{1}{|l|}{ ITEMS } & SA & A & D & SD & MEAN & S.D & DECISIONS \\
\hline 1 & $\begin{array}{l}\text { The library maintains a good relationship with } \\
\text { its clientele. }\end{array}$ & 20 & 17 & 14 & 11 & 3.22 & .26 & Significant \\
\hline 2 & $\begin{array}{l}\text { Clientele have confidence in the library } \\
\text { resources. }\end{array}$ & 18 & 24 & 11 & 9 & 2.91 & .23 & Significant \\
\hline 3 & $\begin{array}{l}\text { We maintain a favourable image of the library } \\
\text { before its users }\end{array}$ & 15 & 21 & 13 & 13 & 2.96 & .24 & Significant \\
\hline 4 & $\begin{array}{l}\text { We evaluate public attitudes towards our } \\
\text { service. }\end{array}$ & 18 & 16 & 13 & 15 & 2,89 & .23 & Insignificant \\
\hline 5 & We establish one on one discussion with users. & 16 & 18 & 16 & 12 & 2.73 & .22 & Insignificant \\
\hline
\end{tabular}

Significant Mean Value $=2.9$

Table 2 presents the item by item mean responses of the Influence of library public relations on effective patronage of University of Uyo Library. The significant mean score is 2.9. Items 1, 2 and 3 are significant because their mean scores is greater than the significant mean value of 2.9 while items 4 and 5 are insignificant because their mean scores are less than the significant mean value of 2.9. The overall decision is that library public relations have a significant influence on the effective patronage of University of Uyo Library.

\section{Testing of Hypotheses}

Hypothesis One (H01): There is no significant influence of resource promotion on effective Patronage of University of Uyo Library. 
Table 3: Independent t-Test Analysis on Resource Promotion on Effective Patronage of University of Uyo Library

\begin{tabular}{lccccccc}
\hline Resource Promotion & $\mathrm{N}$ & Mean & $\begin{array}{l}\text { Standard } \\
\text { Deviation }\end{array}$ & Df & t-cal & t-crit & Decision \\
\hline Resource promotion & 62 & 7.14 & 4.43 & 60 & 2.04 & 1.67 & Significant \\
$\begin{array}{l}\text { Effective patronage of information } \\
\text { resource }\end{array}$ & 62 & 5.82 & 2.61 & 60 & & & \\
\hline
\end{tabular}

Table 4 above reveals that the calculated t-Test value of 2.04 is greater than the critical t-value of 1.67 with 60 degree of freedom at 0.05 level of significance. Thus, the result is significant. Therefore, the null hypothesis which stated that there is no significant influence of resource promotion on effective Patronage of University of Uyo Library is rejected. This implies that there is a significant influence of resource promotion on effective Patronage of University of Uyo Library. The finding from this study agrees with Ezeani (2011) that resource promotion significantly influence patronage and increases students' satisfaction with University of Uyo Library.

Hypothesis Two ( $\left.\mathbf{H O}_{2}\right)$ : There is no significant influence of library public relations on effective Patronage of University of Uyo Library.

Table 4: Independent t-Test Analysis on Library Public Relation on Effective Patronage of University of Uyo Library

\begin{tabular}{lccccccc}
\hline Library Public Relation & $\mathrm{N}$ & Mean & $\begin{array}{l}\text { Standard } \\
\text { Deviation }\end{array}$ & Df & $\mathrm{t}$-cal & $\mathrm{t}$-crit & Decision \\
\hline Library public relation & 62 & 10.3 & 4.52 & 60 & 2.11 & 1.67 & Significant \\
$\begin{array}{l}\text { Effective patronage of } \\
\text { ormation resource }\end{array}$ & inf & 62 & 6.14 & 1.73 & & &
\end{tabular}

ormation resource

Table 4 above shows that the calculated t-test values of 2.11 is greater than the critical t-test value of 1.67 at 0.05 level of significance with 60 degree of freedom. This indicates that the result is significant and the null hypothesis is rejected, which means that there is a significant influence of library public relations on effective Patronage of University of Uyo Library. This finding from this study is in agreement with Capritti and Moreno (2006) who asserted that public relations activities of the library significantly influence the patronage of the library as well as promote the effective marketing of library resources.

\subsection{Conclusion and Recommendation}

The study concluded that marketing indicator such as resource promotion and public relations have significant influence on effective patronage of University of Uyo Library. In view of this, the following recommendations were made;

1. The library management should utilize social media to market their information resource and services to increase users patronage.

2. The library staff should improve their relationships with their fellow staff and their users so as to portray a good image of the library to their users.

3. The library should involve in more publicity of its resources and services by organizing seminars and workshop of publicizing her services to members of the public.

\section{REFERENCES}

Afebende, G. B. and Ebaje, A. S. (2008). Utilization of University Library Facility: A Case Study of Cross River University of Technology, Calabar. Nigerian Library and Information Science Trends, 5(1 \& 2): 29-37.

Capriotti, Q. and Moreno, M. (2006) The Entrepreneur: An Economic Theory (2nd ed.). Edward Elgar Publishers. Available at http://dx.doi.org/10.4337 /9781843765639. Retrieved $13^{\text {th }}$ May 2018 
Chu, M. and Meuleman, Y. (2008). The problems and potential of MySpace and Facebook usage in academic libraries. Internet Reference Services Quarterly, 13(1): 69-85. Available at www.informaworld.com. Retrieved 13 March 2018.

Dickson, A. and Holley, R. P. (2010). Social networking in Academic Libraries: The possibilities and the concerns. School of Library and Information Science Facility Research Publications. Paper 33.

Ekoja, I. I. (2011). Modern ICT Tools: Online Electronic Resources Sharing using Web 2.0 and its implications for library and information practice in Nigeria. Samara Journal of Information Studies, 11(1\&2), 53 58 .

Ezeani, C. N. (2011). Network literacy skills of academic librarians for effective services delivery: The case of University of Nigeria Library System. Library Philosophy and Practice. from http://uidaho.edu/ mbolin/ezeani. htm. Retrieved 25th May 2018

Fakas, M. (2007). Going where patrons are. American Libraries, 38(4), 27-32. www.ebscohost.com http://www.i tc.conversationnet working. Retrieved 24th June, 2018.

Kotler, P., Armstrong, D. and Harry, J. (2007). Marketing analysis, planning, implementation and control. New Jersey: McGraw H ill.

Kunaka, D. (2005). Public relation programmes for library association, http://ifla.organisation.. Retrieved $11^{\text {th }}$ April 2018.

Lautenstager, A.I. (2003). Why you need public relations, Retrieved November 2nd, 2010, from: http://www.enterpreneur.com.

Long, S. (2008). For public relations library marketing training. www.org/marketing/4pr.htm. Retrieved September $15^{\text {th }} 2010$,

Loudon, D. L. and Bitta, D. A. (2002). Consumer Behaviour. New Delhi: Tata McGraw-Hill.

Luck, D. J. (2002). Marketing research. Prentice Hall of India, New Delhi.

Marion, A. and Omotayo, O. (2010). Development of a social networking site with a networked library and conference chat. Journal of Emerging Trends in Computing and information sciences. 2(8), 396-401. Available at http://www.cisjournal.org. Retrieved 23rd September 2013

Murray, A. (2005). Teach yourself public relation. London: Hodder education.

Nwokedi, V. C., and Ogundare, T. (2005). Studies on the Information Needs and Seeking Behaviorsof Science Based Postgraduate Students in a Nigerian University: A Case Study of University of Jos. Borno Library, Archival and Information Science Journal, 2(1): 232-242. 